\title{
Pilotní studie zatížení při bipedální a kvadrupedální chůzi
}

\section{The load at bipedal and quadrupedal walking (Pilot study)}

\author{
Pavel Korvas, Martina Bernaciková, Jan Cacek
}

Fakulta sportovních studií Masarykovy univerzity, Brno

\begin{abstract}
Abstrakt
Práce se zabývá výsledky pilotního výzkumu, který zjištuje rozdily v zatižení u bipedální a kvadrupedální chuize. Šetření bylo zaměřeno na ověreni vhodného metodického postupu pro měření širšího vzorku populace, stanovení vhodných rychlostí, potřebných délek měrených úseků a sklonu terénů. $Z$ výsledků vyplynuly základní rozdíly v zatížení mezi oběma typy chůze a možnost srovnání s uznávanými doporučeními pro udržení nebo zlepšení fyzické kondice u běžné populace. Dosažené výsledky př́padové studie s jedním probandem byly zajímavé zejména z pohledu nárưstu množství rozdílů mezi obèma typy chůze se zvýšením rychlostí a obtížností terénu.
\end{abstract}

\begin{abstract}
The work deals with the results of a pilot research to aimed at the differences in load of bipedal and quadrupedal walking. The aim of the investigation was to verify appropriate methodological procedures for measuring a wider sample of population, determining the appropriate speed, the required length of the measured sections and of terrain gradient. Consecutively we could learn the fundamental differences of load intensity and work out the recommendations to maintain or improve physical fitness of the general population. The results of our study with one proband were particularly attractive in terms of differences between the two types of walking with increasing speed and level of terrain.
\end{abstract}

Klíčová slova: $\quad$ bipedální, chůze, intenzita, kvadrupedální, výdej energie, zatížení

Key words: $\quad$ bipedal, walk, intensity, quadrupedal, energy expenditure, load

\section{ÚVOD}

Pro ovlivnění kvality života a následně zdraví jedince je v současnosti považováno za důležité udržet dostatečnou úroveň fyzické zdatnosti (např. ASCM 1990, Pangrazi 1996, Blair 2001, Zvonař 2009). Využívání pohybových aktivit běžnou populací pro rozvoj a udržení tělesné zdatnosti a tím i zdraví je v současné době nedostatečné, což dokazuje řada průzkumů (Frömel 1999, Blair 2001, Ettinger 2007 a další). Nedostatečné množství pohybové aktivnosti populace se vztahuje na využívání jak nestrukturovaných, tak i strukturovaných pohybů. Studie zaměřené na využívání lokomocí jsou specifickou částí této problematiky (např. Frömel 1999). Motorický vývoj člověka směrem k bipedální lokomoci přispěl postupně k rozvoji jeho inteligence, ale také k postupnému omezení využívání kvadrupedálních činností a lokomocí a společně s dalšími významnými faktory zřejmě také přispěl ke snižování pohybové aktivity a fyzicky náročnějších činností člověka, které udržují jeho pohybovou soustavu na potřebné fyzické úrovni (např. Kračmar 2007, Vele 2006, Zehr 2009). V současné době je větší pravděpodobnost pohybové aktivnosti u běžné populace, a tedy i udržení vyšší fyzické zdatnosti prostřednictvím strukturovaných pohybových aktivit. Z hlediska potřebného déletrvajícího zatížení pro vytvoření dostatečného stimulu pro udržení zdatnosti jsou výhodné především lokomoce. Vliv základních lokomocí je pro dosažení a udržení těchto základních potřeb v současné době zřejmě nezastupitelný, protože běžná populace realizuje stále nejvíce pohybových aktivit prostřednictvím chůze. Řada odborníkủ tvrdí, že jsme dosud chodeckou společností (Fromel 1995 a další). Chůze je ale využívána převážně účelově jako nestrukturovaná aktivita při cestě do školy, zaměstnání apod., ne jako cílená strukturovaná pohybová aktivita v době volného času. To je záležitost jen menší části populace. Své důležité místo zaujímají v pohybové činnosti i kvadrupedální strukturované pohyby odvozené od chůze, které dokáží zaměstnat větší objem svalstva, 
a tak více a intenzivněji působit na rozvoj a udržení zdatnosti a výkonnosti jedince (např. Pandy 1988). Při studiu severské (kvadrupedální) a prosté chůze (bipedální) a srovnávací analýzy pomocí EMG práce vybraných svalů pletence ramenního při zapojení horních končetin do uzavřeného kinetického řetězce výsledky ukazují na koordinační odlišnosti svalové práce (Tlašková 2008). Tento typ lokomocí je běžnou součástí sportovních (strukturovaných) aktivit člověka a má významný vliv na zachování dobré tělesné aktivnosti člověka. Mezi nejznámější a nejčastěji využívané kvadrupedální lokomoce člověka patří zejména běh na lyžích, turistika na lyžích, severská chůze, chůze na sněžnicích, in-line bruslení s holemi (tzv. nordic blading), skialpinismus ve fázi výstupu nebo pohyb na různých trenažérech napodobující tyto lokomoce. Dalším studiem těchto pohybových aktivit je možné přispět k teoretickému poznání rozdílu, výhod a nevýhod bipedálních a kvadrupedálních lokomocí, vyhodnotit jejich účinnost ve vztahu k tělesné zdatnosti a zdraví.

\section{Výzkumný problém}

Zapojení většího objemu svalové hmoty a intenzita pohybové činnosti jsou jedním ze základních kriterií hodnocení potřebné kvality pohybové aktivity. Otázkou je, zda můžeme nalézt při stejných rychlostech u chůze a severské chůze s holemi významné rozdíly v intenzitě zatížení a následně určit možnosti jak více ovlivnit zdatnost některou z těchto lokomocí. Zda tedy můžeme NW označit za strukturovaný pohyb zajištující více zdravotních benefitů než prostá chůze.

Cílem výzkumného šetření je zjistit intenzitu zatížení u chůze a severské chůze v různém terénu při různých rychlostech přesunu a srovnat úroveň hodnot funkčních ukazatelů.

\section{METODIKA}

V rámci pilotního šetření byl sledován jeden proband nadprůměrně zdatný, zkušený turista. Šetření můžeme charakterizovat jako př́padovou studii popisného charakteru.

Tab. 1 Charakteristika měřeného probanda

\begin{tabular}{|c|c|c|c|c|c|c|c|}
\hline počet & pohlaví & věk & Výška $(\mathrm{cm})$ & Hmotnost $(\mathrm{kg})$ & SFmax & $\begin{array}{c}\mathrm{VO}_{2} \max \\
\left(\mathrm{ml}^{\mathrm{kg}} \mathrm{kg}^{-1} \mathrm{~min}^{-1}\right)\end{array}$ & $\mathrm{O}_{2} / \mathrm{SF}\left(\mathrm{ml} \cdot \mathrm{min}^{-1}\right)$ \\
\hline 1 & muž & 52 & 174 & 72 & 173 & 47,2 & 19,9 \\
\hline
\end{tabular}

Šetření proběhlo ve dvou dnech. První den na rovině, druhý den v terénu, ve stoupání a klesáních o průměrném úhlu $7^{\circ}$. Byly zjištovány hodnoty funkčních parametrů při prosté chůzi a chůzi s holemi (tzv. severská chůze) při rychlostech 4,5,6 km/h. Zatížení v každém úseku bylo monitorováno po dobu 3 min., pro hodnocení a srovnání funkční reakce organizmu jedince na jednotlivé rychlosti lokomocí byla brána vždy poslední minuta úseku. Ta odráží stabilizovanou odezvu organizmu na daný podnět. Pro vyšetření byl použit př́stroj Oxycon Mobile (fy Viasis). Z dat, která př́stroj nabízí, jsme vyhodnocovali srdeční frekvenci (SF), tepový kyslík $\left(\mathrm{O}_{2} / \mathrm{SF}\right)$, maximální spotřebu kyslíku $\left(\mathrm{VO}_{2} \mathrm{max}\right)$, relativní spotřebu kyslíku $\left(\mathrm{VO}_{2} \operatorname{max~ml.~} \mathrm{kg}^{-1} \mathrm{~min}^{-1}\right)$, výdej oxidu uhličitého (VCO2), poměr respirační výměny (RER) a plicní ventilaci $\mathrm{V}_{\mathrm{E}}$. Při hodnocení byla použita základní popisná statistika a t-test.

\section{VÝSLEDKY}

Výsledky z měření zatížení při prosté a „severské“ chůzi jsou uvedeny v tabulkách $2-9$. U většiny sledovaných ukazatelů (SF, $\mathrm{O}_{2} / \mathrm{SF}, \mathrm{V}^{\prime} \mathrm{CO} 2, \mathrm{~V}_{\mathrm{E}}$, výdej energie) bylo nalezeno pravidelné zvyšování hodnot při postupně zvyšujícím se zvýšení zatížení organizmu vyšší rychlostí přesunu jak u chůze s holemi tak i bez holí. Výjimkou byly výsledky při chůzi bez holí do kopce při rychlosti $5 \mathrm{~km} / \mathrm{h}$, u které jsme zaznamenali pokles hodnot spotřeby kyslíku $\left(\mathrm{O}_{2} / \mathrm{SF}\right)$ proti nižší rychlosti $(4 \mathrm{~km} / \mathrm{h})$ (tab.4). Zvláštní kapitolou jsou výsledky respiračního kvocientu, které popisujeme samostatně.

Za důležitý indikátor intenzity pohybové aktivity je obecně brána úroveň srdeční frekvence, který může jednoduše využívat i běžná populace. Při chůzi na rovině bez holí i s holemi (tab. 2 a 3 ) se hodno- 
ty SF pohybovaly mezi 40 a $50 \% \mathrm{SF}_{\text {max }}$, přičemž vyšší hodnoty při chůzi s holemi bylo dosaženo až při nejvyšší rychlosti chůze.

Tab.2 Výsledky měření SF chůze bez holí na rovině

\begin{tabular}{|c|c|c|c|c|c|c|c|c|}
\hline $\begin{array}{l}\text { rovina } \\
\text { bez holí }\end{array}$ & & $\begin{array}{c}\mathrm{SF} \\
(\mathrm{min})\end{array}$ & $\begin{array}{c}\mathrm{O}_{2} / \mathrm{SF} \\
\left(\mathrm{ml}^{\left.-\mathrm{min}^{-1}\right)}\right. \\
\end{array}$ & 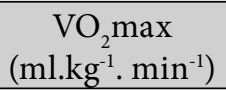 & $\begin{array}{c}\mathrm{V}^{\prime} \mathrm{CO}_{2} \\
\left(\mathrm{ml} \cdot \mathrm{min}^{-1}\right) \\
\end{array}$ & RER & $\begin{array}{c}\mathrm{V}_{\mathrm{E}} \\
\left(1 . \mathrm{min}^{-1}\right)\end{array}$ & $\%$ SFmax \\
\hline \multirow[t]{2}{*}{$4 \mathrm{~km}$} & M & 70,6 & 9,4 & 9,1 & 644,3 & 0,97 & 17,2 & 40,8 \\
\hline & SD & 3,4 & 1,7 & 1,8 & 135,3 & 0,04 & 3,7 & \\
\hline \multirow[t]{2}{*}{$5 \mathrm{~km}$} & $\mathrm{M}$ & 76,8 & 10,3 & 10,7 & 735,3 & 0,94 & 20,0 & 44,4 \\
\hline & SD & 3,1 & 1,9 & 1,9 & 137,0 & 0,04 & 3,4 & \\
\hline \multirow[t]{2}{*}{$6 \mathrm{~km}$} & M & 81,2 & 12,0 & 13,4 & 913,1 & 0,93 & 24,3 & 46,9 \\
\hline & SD & 2,3 & 1,6 & 1,8 & 135,1 & 0,05 & 4,0 & \\
\hline
\end{tabular}

Tab.3 Výsledky měření chůze s holemi na rovině

\begin{tabular}{|c|c|c|c|c|c|c|c|c|}
\hline $\begin{array}{c}\text { rovina } \\
\text { s holemi }\end{array}$ & & $\begin{array}{c}\text { SF } \\
(\mathrm{min})\end{array}$ & $\begin{array}{c}\mathrm{O}_{2} / \mathrm{SF} \\
\left(\mathrm{ml} \cdot \mathrm{min}^{-1}\right) \\
\end{array}$ & 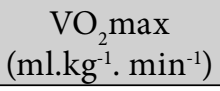 & $\begin{array}{c}\mathrm{V}^{\prime} \mathrm{CO}_{2} \\
\left(\mathrm{ml}^{\left.-\mathrm{min}^{-1}\right)}\right. \\
\end{array}$ & RER & $\begin{array}{c}\mathrm{V}_{\mathrm{E}} \\
\left(1 . \mathrm{min}^{-1}\right) \\
\end{array}$ & $\%$ SFmax \\
\hline \multirow[t]{2}{*}{$4 \mathrm{~km}$} & $\mathrm{M}$ & 70,1 & 9,5 & 9,1 & 639,2 & 0,96 & 19,8 & 40,5 \\
\hline & SD & 3,3 & 2,3 & 2,3 & 163,2 & 0,05 & 4,9 & \\
\hline \multirow[t]{2}{*}{$5 \mathrm{~km}$} & $\mathrm{M}$ & 75,6 & 10,9 & 11,3 & 768,1 & 0,93 & 21,2 & 43,7 \\
\hline & SD & 5,4 & 3,7 & 3,5 & 236,4 & 0,06 & 7,0 & \\
\hline \multirow[t]{2}{*}{$6 \mathrm{~km}$} & $\mathrm{M}$ & 84,9 & 13,1 & 15,2 & 1013,9 & 0,91 & 27,1 & 49,0 \\
\hline & SD & 2,3 & 2,2 & 2,5 & 177,5 & 0,03 & 4,8 & \\
\hline
\end{tabular}

Při chůzi na rovině nebyly nalezeny rozdíly v hodnotách SF mezi chůzí s holemi a bez holí při rychlostech $4 \mathrm{~km} / \mathrm{h}\left(\mathrm{p}_{4}=0,281\right)$ a při $5 \mathrm{~km} / \mathrm{h}\left(\mathrm{p}_{5}=0,153\right)$. Významný rozdíl byl zjištěn až při nejvyšší měřené intenzitě zatížení při $6 \mathrm{~km} / \mathrm{h}\left(\mathrm{p}_{6}=0,000\right)$ ve prospěch chůze $s$ holemi.

U všech měření chůze $\mathbf{v}$ náročnějším terénu (do kopce) překročila intenzita zatížení výrazně hodnotu $50 \% \mathrm{SF}_{\max }$. Při chůzi do kopce bez i s holemi bylo dosaženo již od $5 \mathrm{~km} / \mathrm{h}$ zatížení překračující $60 \%$ $\mathrm{SF}_{\max }$. Při chůzi s holemi do kopce rychlostí $6 \mathrm{~km} / \mathrm{h}$ se úroveň zatížení přiblížila hranici $70 \% \mathrm{SF}_{\max }$, což znamená poměrně vysokou vyšší intenzitu zatížení pro rekreační aktivitu.

Tab.4 Výsledky měření chůze bez holí do kopce

\begin{tabular}{|c|c|c|c|c|c|c|c|c|}
\hline $\begin{array}{l}\text { bez holí } \\
\text { do kopce }\end{array}$ & & $\begin{array}{c}\mathrm{SF} \\
(\mathrm{min})\end{array}$ & 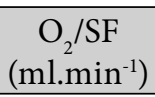 & $\begin{array}{c}\mathrm{VO}_{2} \max \\
\left(\mathrm{ml} \cdot \mathrm{kg}^{-1} \cdot \mathrm{min}^{-1}\right)\end{array}$ & 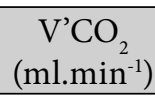 & RER & $\begin{array}{c}\mathrm{V}_{\mathrm{E}} \\
\left(1 . \mathrm{min}^{-1}\right)\end{array}$ & \%SFmax \\
\hline \multirow[t]{2}{*}{$4 \mathrm{~km}$} & M & 100,4 & 15,8 & 21,9 & 1389,4 & 0,88 & 34,6 & 58,0 \\
\hline & SD & 7,5 & 2,5 & 4,4 & 246,7 & 0,05 & 5,5 & \\
\hline \multirow[t]{2}{*}{$5 \mathrm{~km}$} & $\mathrm{M}$ & 105,2 & 14,8 & 21,7 & 1430,7 & 0,95 & 37,4 & 60,8 \\
\hline & SD & 8,7 & 5,3 & 8,5 & 468,0 & 0,18 & 11,1 & \\
\hline \multirow[t]{2}{*}{$6 \mathrm{~km}$} & $\mathrm{M}$ & 113,8 & 16,3 & 25,7 & 1678,6 & 0,93 & 42,1 & 65,8 \\
\hline & SD & 10,5 & 4,1 & 7,6 & 405,9 & 0,13 & 8,7 & \\
\hline
\end{tabular}


Tab.5 Výsledky měření chůze s holemi do kopce

\begin{tabular}{|c|c|c|c|c|c|c|c|c|}
\hline $\begin{array}{c}\text { do kopce } \\
\text { s holemi }\end{array}$ & $\begin{array}{c}\mathrm{SF} \\
(\mathrm{min})\end{array}$ & $\begin{array}{c}\mathrm{O}_{2} / \mathrm{SF} \\
\left(\mathrm{ml}^{\left.-\mathrm{min}^{-1}\right)}\right.\end{array}$ & $\begin{array}{c}\mathrm{VO}_{2} \mathrm{max} \\
\left(\mathrm{ml}^{-1} \mathrm{~kg}^{-1} \cdot \mathrm{min}^{-1}\right)\end{array}$ & $\begin{array}{c}\mathrm{V}^{\prime} \mathrm{CO}_{2} \\
\left(\mathrm{ml}^{-1} \mathrm{~min}^{-1}\right)\end{array}$ & RER & $\begin{array}{c}\mathrm{V}_{\mathrm{E}} \\
\left(1 . \mathrm{min}^{-1}\right)\end{array}$ & \%SFmax \\
\hline $4 \mathrm{~km} / \mathrm{h}$ & $\mathrm{M}$ & 101,0 & 15,7 & 21,1 & 1345,9 & 0,88 & 36,8 & 58,4 \\
\hline & $\mathrm{SD}$ & 3,0 & 2,8 & 4,8 & 256,1 & 0,06 & 6,3 & \\
\hline $5 \mathrm{~km} / \mathrm{h}$ & $\mathrm{M}$ & 109,9 & 17,7 & 26,8 & 1714,0 & 0,88 & 45,3 & 63,5 \\
\hline & $\mathrm{SD}$ & 6,6 & 2,6 & 4,9 & 296,7 & 0,04 & 7,4 & \\
\hline $6 \mathrm{~km} / \mathrm{h}$ & $\mathrm{M}$ & 118,2 & 17,8 & 29,2 & 1901,1 & 0,90 & 50,3 & 68,3 \\
\hline & $\mathrm{SD}$ & 9,7 & 3,7 & 7,3 & 444,1 & 0,08 & 11,2 & \\
\hline
\end{tabular}

Při srovnání chůze do kopce bez a s holemi byl zjištěn významný rozdíl mezi hodnotami SF u všech sledovaných rychlostí $\left(\mathrm{p}_{4}=0,036, \mathrm{p}_{5}=0,008, \mathrm{p}_{6}=0,046\right)$. To je zřejmě terén, ve kterém dochází $\mathrm{k}$ výrazně většímu zapojení horní části těla do pohybu chodce.

Při chůzi $\mathbf{z}$ kopce $\mathbf{s}$ holemi byly nalezeny mírně vyšší hodnoty zatížení organizmu než při chůzi $\mathbf{z}$ kopce bez holí u všech rychlostí přesunu. SF se pohybovala u obou variant v rozsahu $44,5-53,0 \% \mathrm{SF}_{\max }$. To jsou vyšší hodnoty než při chůzi na rovině srovnatelnou rychlostí. Zatížení při obou vyšších rychlostech se pohybovalo v oblasti $50 \% \mathrm{SF}_{\max }$.

$Z$ výsledků hodnot SF u chůze $\mathbf{z}$ kopce $\mathbf{s}$ holemi a bez holí byly zjištěny významné rozdíly mezi hodnotami SF dosaženými pro všechny rychlosti přesunu, $\mathrm{p}_{4}=0,000, \mathrm{p}_{5}=0,000, \mathrm{p}_{6}=0,000$.

Tab.6 Výsledky měření chůze bez holí z kopce

\begin{tabular}{|c|c|c|c|c|c|c|c|c|}
\hline $\begin{array}{c}\text { bez holí } \\
\text { z kopce }\end{array}$ & SF (min) & $\begin{array}{c}\mathrm{O}_{2} / \mathrm{SF} \\
\left(\mathrm{ml}_{\mathrm{min}}^{-1}\right)\end{array}$ & $\begin{array}{c}\mathrm{VO}_{2} \mathrm{max} \\
\left(\mathrm{ml}^{-1} \mathrm{~kg}^{-1} \mathrm{~min}^{-1}\right)\end{array}$ & $\begin{array}{c}\mathrm{V}^{\prime} \mathrm{CO}_{2} \\
\left(\mathrm{ml}^{\left.-\mathrm{min}^{-1}\right)}\right.\end{array}$ & RER & $\begin{array}{c}\mathrm{V}_{\mathrm{E}} \\
\left(\mathrm{l}_{\mathrm{min}}{ }^{-1}\right)\end{array}$ & \%SFmax \\
\hline $4 \mathrm{~km} / \mathrm{h}$ & $\mathrm{M}$ & 77,0 & 8,9 & 9,4 & 822,6 & 1,22 & 22,8 & 44,5 \\
\hline & $\mathrm{SD}$ & 3,6 & 2,2 & 2,4 & 174,0 & 0,09 & 4,6 & \\
\hline $5 \mathrm{~km} / \mathrm{h}$ & $\mathrm{M}$ & 84,1 & 8,5 & 10,9 & 979,0 & 1,24 & 26,5 & 48,6 \\
\hline & $\mathrm{SD}$ & 2,2 & 2,7 & 2,6 & 233,0 & 0,07 & 6,1 & \\
\hline $6 \mathrm{~km} / \mathrm{h}$ & $\mathrm{M}$ & 89,1 & 9,0 & 11,9 & 1041,0 & 1,20 & 29,8 & 51,5 \\
\hline & $\mathrm{SD}$ & 1,3 & 2,3 & 1,8 & 181,9 & 0,07 & 4,0 & \\
\hline
\end{tabular}

Tab.7 Výsledky měření chůze s holemi z kopce

\begin{tabular}{|c|c|c|c|c|c|c|c|c|}
\hline $\begin{array}{c}\text { z kopce } \\
\text { s holemi }\end{array}$ & SF (min) & $\begin{array}{c}\mathrm{O}_{2} / \mathrm{SF} \\
\left(\mathrm{ml}^{\left.-\mathrm{min}^{-1}\right)}\right.\end{array}$ & $\begin{array}{c}\mathrm{VO}_{2} \mathrm{max} \\
\left(\mathrm{ml}^{-1} \mathrm{~kg}^{-1} \mathrm{~min}^{-1}\right)\end{array}$ & $\begin{array}{c}\mathrm{V}^{\prime} \mathrm{CO}_{2} \\
\left(\mathrm{ml}^{\left.-\mathrm{min}^{-1}\right)}\right.\end{array}$ & RER & $\begin{array}{c}\mathrm{V}_{\mathrm{E}} \\
\left(\mathrm{l}^{-1} \mathrm{~min}^{-1}\right)\end{array}$ & $\%$ SFmax \\
\hline $4 \mathrm{~km} / \mathrm{h}$ & $\mathrm{M}$ & 80,7 & 9,1 & 10,0 & 787,3 & 1,08 & 24,6 & 46,6 \\
\hline & $\mathrm{SD}$ & 1,2 & 1,8 & 2,0 & 162,0 & 0,04 & 4,3 & \\
\hline $5 \mathrm{~km} / \mathrm{h}$ & $\mathrm{M}$ & 88,4 & 9,2 & 11,1 & 918,5 & 1,13 & 27,6 & 51,1 \\
\hline & $\mathrm{SD}$ & 1,4 & 1,6 & 1,9 & 164,1 & 0,05 & 4,8 & \\
\hline $6 \mathrm{~km} / \mathrm{h}$ & $\mathrm{M}$ & 91,7 & 9,5 & 11,9 & 1024,6 & 1,17 & 31,4 & 53,0 \\
\hline & $\mathrm{SD}$ & 1,7 & 1,2 & 1,5 & 168,3 & 0,08 & 4,1 & \\
\hline
\end{tabular}

Procentuální rozdíly hodnot SF u chůze na rovině a obou variant chůze v terénu jsou zřetelné, i když sklon stoupání byl jen $7^{\circ}$. Toto vyšší zatížení je zajímavé především u chůze z kopce, u níž jsme předpokládali podobné hodnoty jako u chůze na rovině. $\mathrm{V}$ tabulce č. 8 jsou srovnány vždy jednotlivé typy chůze s holemi a bez holí při stejné rychlosti. 
Tab.8 Procentuální zvýšení hodnot SF u jednotlivých typů chůze při sledovaných rychlostech proti chůzi na rovině

\begin{tabular}{|c|c|c|c|c|}
\hline & Bez holí do kopce & Bez holí $\mathrm{z}$ kopce & S holemi do kopce & S holemi $\mathrm{z}$ kopce \\
\hline $4 \mathrm{~km} / \mathrm{h}$ & 42,2 & 9,1 & 44,0 & 15,1 \\
\hline $5 \mathrm{~km} / \mathrm{h}$ & 36,9 & 9,5 & 45,4 & 16,9 \\
\hline $6 \mathrm{~km} / \mathrm{h}$ & 40,1 & 9,7 & 39,2 & 8,0 \\
\hline
\end{tabular}

\section{Rozdíly mezi jednotlivými typy chůze stejnou rychlostí u vybraných respiračních ukazatelů}

Hodnoty sledovaných respiračních parametrů zjištěné při chůzí bez holí a s holemi (bi- a kvadrupedální pohyb) při stejných rychlostech ve stejném terénu jsou uvedeny v tab. 3 - 7. Parametry, které v této části hodnotíme, jsou tepový kyslík $\left(\mathrm{VO}_{2} / \mathrm{SF}\right)$, výdej $\mathrm{CO}_{2}\left(\mathrm{~V}^{\prime} \mathrm{CO}_{2}\right)$ a plicní ventilace $\left(\mathrm{V}_{\mathrm{E}}\right)$. Nejvyšší hodnoty respiračních ukazatelů byly logicky zjištěny při chůzi stejnou rychlostí do stoupání u chůze prosté i s holemi. Nejnižší úroveň zatížení byla zjištěna u obou typů chůze na rovině, což je výsledek méně očekávaný, spiše jsme předpokládali nejnižší hodnoty u chůze z kopce.

U tepového kyslíku byly nejnižší hodnoty zjištěny při chůzi z kopce (s i bez holí, 39,4-44,0\% z maximální hodnoty zjištěné při laboratorním testu) a nejvyšší podle předpokladu při chůzi do kopce (72,7$82,4 \%)$. U tohoto parametru na rozdíl od hodnot SF, chůze na rovině znamenala vy̌šśí zatížení než chůze z kopce, v rozmezí 44,0 - 60,6\% z maximální hodnoty.

Nejnižší hodnoty $\mathrm{VO}_{2} \max \cdot \mathrm{kg}^{-1} \cdot \mathrm{min}^{-1}$ byly zjištěny při chůzi na rovině bez i s holemi $(19,3-32,2 \%)$ a nejvyšší při chůzi do stoupání (44,7 - 61,9\%). Při chůzi z kopce byly zjištěné hodnoty velmi rozdílné, bez holí 19,9 - 25,2\%, s holemi 42,1 - 44,0\%. U dalších dvou respiračních parametrů výdeje $\mathrm{CO}_{2}$ a plicní ventilace byly zjištěné hodnoty vždy nejnižší u chůze na rovině (bez holí i s holemi) a nejvyšší vždy do kopce (opět bez i s holemi). U chůze na rovině byly hodnoty $\mathrm{V}^{\prime} \mathrm{CO}_{2}$ zjištěny v rozsahu 13,3 - 21,1\% z maximálních hodnot zjištěných při laboratorním testu, při chůzi do kopce $28,0-39,5 \%$. Plicní ventilace dosáhla při chůzi do kopce hodnot v rozsahu $24,2 \%-35,2 \%$ a na rovině $12,0-19,0 \% \mathrm{z}$ maximálních hodnot probanda.

Při srovnání chůze bez holí a s holemi na rovině byl nalezen jen jeden významný rozdíl př̀ rychlostech přesunu 4 a $5 \mathrm{~km} / \mathrm{h}$. Pro $\mathrm{V}_{\mathrm{E}}$ při rychlosti $4 \mathrm{~km} / \mathrm{h} \mathrm{p}=0,027$. U zbývajících ukazatelů př̀i těchto rychlostech chůze jsme žádné významné rozdíly nezjistili. Signifikantní rozdíly pro všechny uvedené ukazatele byly nalezeny až při rychlosti $6 \mathrm{~km} / \mathrm{h}\left(\mathrm{p}_{\mathrm{SF}}=0,000, \mathrm{p}_{\mathrm{O} 2 / \mathrm{SF}}=0,014, \mathrm{p}_{\mathrm{VO} 2 \max / \mathrm{kg} / \min }=0,0006, \mathrm{p}_{\mathrm{VCO} 2}=0,000\right.$, $\left.\mathrm{p}_{\mathrm{VE}}=0,005\right)$.

Při chůzi do kopce bez a s holemi nebyl zjištěn u uvedených tři respiračních ukazatelů žádný významný rozdíl při nejnižší sledované rychlosti chůze $(4 \mathrm{~km} / \mathrm{h})$. Při obou vyšších rychlostech již byly všechny rozdíly významné. Při $5 \mathrm{~km} / \mathrm{h} \mathrm{p}_{\mathrm{O} 2 / \mathrm{SF}}=0,005, \mathrm{p}_{\mathrm{VO} 2 \max / \mathrm{kg} / \min }=0,004, \mathrm{p}_{\mathrm{VCO} 2}=0,005, \mathrm{p}_{\mathrm{VE}}=0,001$, při $6 \mathrm{~km} / \mathrm{h} \mathrm{p}_{\mathrm{O} 2 /}$ $\mathrm{SF}=0,002, \mathrm{p}_{\mathrm{VO} 2 \max / \mathrm{kg} / \mathrm{min}}=0,002, \mathrm{p}_{\mathrm{VCO} 2}=0,002, \mathrm{p}_{\mathrm{VE}}=0,000$.

Při chůzi $\mathbf{z}$ kopce $\mathbf{s}$ holemi byly nalezeny jen mírně vyšší hodnoty zatížení organizmu než při chůzi z kopce bez holí u všech rychlostí přesunu, Proto zjištěné rozdíly hodnot u sledovaných respiračních ukazatelů při stejné rychlosti byly nesignifikantní.

Při srovnání chůze na rovině s chůzí do kopce bez i s holemi byly všechny rozdíly při stejné rychlosti významné u všech postupných rychlostí (vše $\mathrm{p}=0,000$ ).

Při srovnání chůze na rovině $\mathbf{s}$ chůzí $\mathbf{z}$ kopce bez holí byly zjištěny významné rozdíly pro všechny ukazatele u obou nejvyšších sledovaných rychlostí. U $4 \mathrm{~km} / \mathrm{h}$ byly významné rozdíly zjištěny pro $\mathrm{VCO} 2$ $(\mathrm{p}=0,000)$ a $\mathrm{V}_{\mathrm{E}}(0,000)$. Mezi chůzí na rovině a $\mathrm{z}$ kopce $\mathbf{s}$ holemi byly zjištěny rozdíly pro všechny rychlosti jen pro srdeční frekvenci a plicní ventilaci. Dále byly nalezeny významné rozdíly pro VCO2 při 4 a 5 $\mathrm{km} / \mathrm{h}\left(\mathrm{p}_{4}=0,002, \mathrm{p}_{5}=0,004\right)$ pro $6 \mathrm{~km} / \mathrm{h}$ pro tepový kyslík $\left(\mathrm{p}_{\mathrm{O} / \mathrm{SF}}=0,011\right)$.

\section{Rozdíly v zatížení u jednotlivých typů chůze a terénů mezi zvyšujícími se rychlostmi}

Dále jsme zjištovali u vybraných respiračních ukazatelů, zda zatížení u jednotlivých typů chůze se postupně zvyšuje a rozdíly $\mathrm{v}$ naměřených hodnotách odpovídají narůstajícím rychlostem. 
U prosté chůze na rovině byly rozdíly hodnot zjištěných mezi jednotlivými rychlostmi vždy významné, podobně i u severské chůze na rovině (vše $\mathrm{p}=0,000$ ).

Při chůzi do kopce bez holí nebyly prokázány významné změny u sledovaných ukazatelů mezi rychlostmi 4 a $5 \mathrm{~km} / \mathrm{h}$. Při srovnání hodnot mezi rychlostmi 4 a $6 \mathrm{~km} / \mathrm{h}$ a 5 a $6 \mathrm{~km} / \mathrm{h}$ již byly rozdíly u většiny uvedených parametrů statisticky významné s výjimkou tepového kyslíku $\left(\mathrm{p}_{4-6}=0,301, \mathrm{p}_{5-6}=0,099\right)$. Při chůzi do kopce s holemi jsme zjistili významné rozdíly pro všechny vybrané respirační ukazatele mezi výsledky při chůzí nejnižší rychlostí a oběma vyššími $(4$ a $5 \mathrm{~km} / \mathrm{h}, 4$ a $6 \mathrm{~km} / \mathrm{h})$. Mezi rychlostmi 5 a $6 \mathrm{~km} / \mathrm{h}$ byly nalezeny významné rozdíly jen pro SF $\left(\mathrm{p}_{\mathrm{SF}}=0,043\right), \mathrm{VCO}_{2}\left(\mathrm{p}_{\mathrm{vCO} 2}=0,032\right)$ a $\mathrm{V}_{\mathrm{E}}\left(\mathrm{p}_{\mathrm{vE}}=0,024\right)$. Nebyly zjištěny rozdíly u parametrů ukazujících spotřebu kyslíku mezi rychlostmi 5 a $6 \mathrm{~km} / \mathrm{h}\left(\mathrm{p}_{\mathrm{vO} 2 /}\right.$ $\mathrm{SF}=0,076)$.

Srovnání rozdílů př̀i chůzi bez holí z kopce bylo významné mezi nejnižší rychlostí a oběma vyššími u většiny vybraných ukazatelů. Výjimku tvořily hodnoty pro tepový kyslík mezi rychlostmi $4 \mathrm{a} 5 \mathrm{~km} / \mathrm{h}$, $\mathrm{p}_{4-5}=0,308$ a mezi 5 a $6 \mathrm{~km} / \mathrm{h}, \mathrm{p}_{5-6}=0,134$. Mezi nejvyššími rychlostmi $(5$ a $6 \mathrm{~km} / \mathrm{h})$ žádný významný rozdíl nebyl nalezen.

Při chůzi $\mathbf{z}$ kopce $\mathbf{s}$ holemi byly sledované hodnoty mezi zvyšujícími se rychlostmi většinou významně rozdílné. Výjimku tvořily nesignifikantní rozdíly u tepového kyslíku $\left(\mathrm{p}_{4-5}=0,43, \mathrm{p}_{4-6}=0,18, \mathrm{p}_{5-6}=0,22\right)$.

\section{Poměr respirační výměny}

Hodnocení výsledků poměru respirační výměny (RER) je samostatnou částí popisu výsledků, protože zde byly zjištěny málo očekávané výsledky. Při chůzi na rovině i do kopce hodnoty RER odpovídaly předpokladům při dané intenzitě zatížení $(0,9)$, ovšem při chůzi z kopce bez i s holemi při stejné rychlosti převýšily hodnotu 1,0 .

U prosté chůze na rovině byl zjištěn postupný pokles hodnot RER se zvyšující se rychlostí (tab.2). Rozdíly mezi hodnotami u postupně se zvyšujících rychlostí byly významné mezi 4 a $5 \mathrm{~km} / \mathrm{h}\left(\mathrm{p}_{4}\right.$. $\left.{ }_{5}=0,000\right)$ a také mezi 4 a $6 \mathrm{~km} / \mathrm{h}\left(\mathrm{p}_{4-6}=0,000\right)$. Pro hodnoty mezi 5 a $6 \mathrm{~km} / \mathrm{h}$ významnost rozdílů nalezena nebyla $\left(\mathrm{p}_{5-6}=0,437\right)$. Podobně i u severské chůze s holemi na rovině byl zjištěn postupný pokles hodnot RER (tab.3). Opět byly zjištěny významné rozdíly mezi hodnotami zjištěnými u chůze rychlostmi 4 a $5 \mathrm{~km} / \mathrm{h}\left(\mathrm{p}_{4-5}=0,000\right)$ i mezi 4 a $6 \mathrm{~km} / \mathrm{h}\left(\mathrm{p}_{4-6}=0,000\right)$. Mezi dvěma nejvyššími rychlostmi chůze významný rozdíl zjištěn nebyl $\left(\mathrm{p}_{5-6}=0,088\right)$. Při srovnání výsledků obou typů chůzí na rovině při stejných rychlostech postupu jsme zjistili nesignifikantní rozdíly při obou nejnižších rychlostech $\left(\mathrm{p}_{4}=0,42, \mathrm{p}_{5}=0,334\right)$. Významný rozdíl byl zjištěn až pro nejvyšší zatížení při rychlosti $6 \mathrm{~km} / \mathrm{h}\left(\mathrm{p}_{6}=0,004\right)$.

Při chůzi do kopce bez holí výsledky RER vykázaly nepravidelné zvýšení hodnot se zvyšujícím se zatížením (tab 4.) v rozsahu 0,88 - 0,95. Nejvyšší hodnota byla zjištěna při $5 \mathrm{~km} / \mathrm{h}$. Významný rozdíl mezi hodnotami u zvyšujícího se zatížení byl zjištěn jen mezi nejnižšími rychlostmi postupu ( $\mathrm{p}_{4}$ $\left.{ }_{5}=0,009\right)$. Při chůzi do kopce s holemi byl zjištěn minimální rozsah hodnot RER u sledovaných rychlostí přesunu $(0,88-0,90)$, proto nebyly nalezeny žádné významné rozdíly mezi hodnotami při zvyšující se rychlostí $\left(\mathrm{p}_{4-5}=0,137, \mathrm{p}_{4-6}=0,291, \mathrm{p}_{5-6}=0,059\right)$. Mezi oběma typy chůze př̀i chůzi do kopce byl zjištěn významný rozdíl jen pro rychlost $5 \mathrm{~km} / \mathrm{h}\left(\mathrm{p}_{4}=0,261, \mathrm{p}_{5}=0,009, \mathrm{p}_{6}=0,182\right)$.

Při chůzi bez holí z kopce hodnoty RER překročily hodnotu 1,0 a kolísaly v minimálním rozsahu (1,2 - 1,24). Významný rozdíl byl nalezen jen mezi nejvyššími rychlostmi $\left(5-6 \mathrm{~km} / \mathrm{h}, \mathrm{p}_{5-6}=0,026\right)$. Při chůzi $\mathbf{z}$ kopce s holemi jsme zaznamenali pravidelné zvýšení hodnot se zvyšujícím se zatížením v rozmezí $1,08-1,17$. Významné rozdíly byly nalezeny mezi všemi rychlostmi $\left(\mathrm{p}_{4-6}=0,000, \mathrm{p}_{4-5}=0,000, \mathrm{p}_{5-6}=0,038\right)$. Při srovnání obou typů chůze $\mathbf{z}$ kopce jsme zjistili rozdíly v hodnotách RER jen pro dvě nižší rychlosti pohybu $\left(\mathrm{p}_{4}=0,000, \mathrm{p}_{5}=0,000, \mathrm{p}_{6}=0,135\right)$.

\section{Výdej energie}

Široce využívaným kriteriem pro hodnocení zatížení u různých pohybových aktivit nebo pohybových programů je výdej energie. Výsledky tohoto ukazatele u jednotlivých typů chůze při zvyšující se rychlosti jsou uvedeny v tab. 9. 


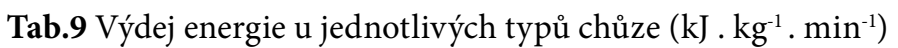

\begin{tabular}{|c|c|c|c|c|c|c|}
\hline rychlost & $\begin{array}{c}\text { rovina } \\
\text { bez holí }\end{array}$ & $\begin{array}{c}\text { rovina } \\
\text { s holemi }\end{array}$ & $\begin{array}{c}\text { do kopce } \\
\text { bez holí }\end{array}$ & $\begin{array}{c}\text { do kopce } \\
\text { s holemi }\end{array}$ & $\begin{array}{c}\text { z kopce } \\
\text { bez holí }\end{array}$ & $\begin{array}{c}\text { z kopce } \\
\text { s holemi }\end{array}$ \\
\hline $4 \mathrm{~km} / \mathrm{h}$ & 0,189 & 0,189 & 0,433 & 0,479 & 0,223 & 0,214 \\
\hline $5 \mathrm{~km} / \mathrm{h}$ & 0,223 & 0,239 & 0,449 & 0,491 & 0,239 & 0,248 \\
\hline $6 \mathrm{~km} / \mathrm{h}$ & 0,277 & 0,315 & 0,542 & 0,643 & 0,260 & 0,269 \\
\hline
\end{tabular}

Nejvyšší výdej byl podle předpokladu zjištěn u chůze do kopce s holemi i bez holí jak absolutně, tak i při srovnání se stejnými rychlostmi chůze v jiném terénu. Nejnižší hodnoty byly zaznamenány př̀i chůzi na rovině při rychlostech 4 a $5 \mathrm{~km} / \mathrm{h}$. Při nejvyšší rychlosti byl nejnižší výdej zjištěn u chůze z kopce s i bez holí. Rozdíly v množství výdeje energie mezi typy chůze při stejné rychlosti a ve stejném terénu byly zjištěny jen při chůzi do kopce rychlostí 5 a $6 \mathrm{~km} / \mathrm{h}\left(\mathrm{p}_{5}=0,013\right.$ a $\left.\mathrm{p}_{6}=0,001\right)$ a při chůzi na rovině rychlostí $6 \mathrm{~km} / \mathrm{h}\left(\mathrm{p}_{4}=0,001\right)$.

Rozdíly mezi výdejem energie při chůzi na rovině a do kopce byly významné pro všechny rychlosti postupu i typy chůze (vše $\mathrm{p}=0,000$ ).

Při srovnání výdeje množství energie při chůzi na rovině a $\mathbf{z}$ kopce byly rozdílné výsledky jen u chůze severské. Při severské chůzi s holemi byly rozdíly významné pro 4 a $6 \mathrm{~km} / \mathrm{h}\left(\mathrm{p}_{4}=0,044, \mathrm{p}_{6}=0,002\right)$, pro $5 \mathrm{~km} / \mathrm{h}$ významnost nebyla nalezena $\left(\mathrm{p}_{5}=0,294\right)$.

Ve výsledcích můžeme sledovat významně vyšší výdej energie při chůzi z kopce s holemi než na rovině při nízké rychlosti $(4 \mathrm{~km} / \mathrm{h})$. Při střední měřené rychlosti jsou výsledky vyrovnané (bez rozdílů) a opět rozdílné při nejvyšším zatížení $(6 \mathrm{~km} / \mathrm{h})$, př̀i němž byl větší výdej nalezl u chůze na rovině.

\section{DISKUZE}

Hlavním cílem prŕpadové studie bylo srovnání zatížení organizmu jedince při bipedální a kvadrupedální chůzi v různém druhu terénu. Obě pohybové činnosti jsou neurofyziologicky organizovány ve zkř́iženém lokomočním vzoru (Bačáková 2008b) a patří mezi strukturované aktivity člověka.

Při srovnání zatížení organizmu u obou typů chůze začínají rozdíly u zdatného jedince na rovině při rychlosti $6 \mathrm{~km} / \mathrm{h}$, do kopce již od $5 \mathrm{~km} / \mathrm{h}$ pro všechny sledované parametry (do kopce od $4 \mathrm{~km} / \mathrm{h}$ jen pro SF). U chůze z kopce byly zjištěny rozdíly jen pro SF a RER u všech zkoumaných rychlostí chůze. Uvedená srovnání naznačují tendenci (u zdatného jedince) většího zapojení horních končetin do tvorby hybných sil na rovině, a do kopce až při vyšších rychlostech pohybu. Při chůzi z kopce pomáhá vytváření hybných sil ve směru přesunu gravitace, přesto jsou hodnoty sledovaných parametrů vyšší než na rovině. Při pohybu z kopce aktivněji působí dolní končetiny. Ty vykonávají v závislosti na sklonu i brzdivé pohyby. Horní končetiny při zatížení zřejmě hrají malou roli, jen v prudším klesání mohou pomáhat brzdit rychlost pohybu. Tyto výsledky naznačují nízké zapojení horních končetin zdatnějšího jedince při rychlosti $4 \mathrm{~km} / \mathrm{h}$ ve všech sledovaných terénních profilech. Nízká rychlost pohybu a délka kroku zřejmě nedostatečně iniciuje činnost svalstva pletence ramenního a paže. Při vyšší rychlosti chodec obvykle prodlužuje krok a paže mohou pracovat ve větším rozsahu pohybu tak, že to významně ovlivňuje změny v zatížení organizmu chodce. Přes vysokou míru príbuznosti vrozených pohybových vzorů s prací pletence ramenního při chůzi s holemi může mít vyšší náročnost při severské chůzi příčinu v určitých koordinačních odlišnostech proti chůzi volné (Kračmar, Suchý 2007, Tlašková 2008b). Může to znamenat, že nejen zapojením většího počtu svalových skupin do tvorby hybných sil při kvadrupedálním pohybu, ale i možný časový posun při zapojování svalových skupin pletence ramenního, pánve a částečné přenesení aktivity z ventrální na dorzální stranu trupu může mít vliv na vyšší intenzitu zatížení při kvadrupedální chůzi (Kračmar 2007, Bačáková 2008a, Bačáková 2008b). Je zřejmé, že jsou potřebná další šetření pro získání podrobnějších výsledků pro analýzu. Současně je nutné poznamenat, že rychlosti chůze na rovině $6 \mathrm{~km} / \mathrm{h}$ a výše, stejně tak $5 \mathrm{~km} / \mathrm{h}$ a výše do kopce využívá běžná populace nebo rekreační turisté jen velmi málo a průměrná rychlost $5 \mathrm{~km} / \mathrm{h}$ a vyšší ve stoupání je náročná i pro zdatnějšího chodce. U průměrné populace jsou tyto rychlosti již při chůzi na rovině subjektivně velmi vysokým zatížením. 
Hodnoty srdeční frekvence při chůzi na rovině bez i s holemi se při daných rychlostech pohybovaly $\mathrm{v}$ rozsahu $40-50$ \% SFmax. Protože proband byl zdatný jedinec, můžeme u průměrné populace uvažovat o zatížení spíše mírně vyšším, v oblasti 50 \% SFmax. To je úroveň, kterou můžeme považovat za dostatečnou pro udržení fyzické nebo kardiopulmonální zdatnosti organizmu. Při chůzi do kopce byly podle předpokladu zjištěny nejvyšší hodnoty SF ze všech tř́i testovaných druhů terénu. U většiny rychlostí chůze ve stoupání přesáhly hodnoty SF 60 \% SFmax. To znamená i možnost rozvoje kardiopulmonálních funkcí, zejména při nejvyšších rychlostech, kdy při severské chůzi s holemi se hodnoty blížily hranici 70 \% SF max. Při obou vyšších rychlostech na rovině jsou výsledky podobné jako u Schwarze (2006), který testoval starší jedince při prosté chůzi v laboratorních podmínkách. Méně očekávanými byly výsledky chůze z kopce u obou variant, kde jsme zjistili vyšší hodnoty SF než u chůze na rovině při stejných rychlostech. Úroveň zatížení se pohybovala mezi 44-53\% SFmax, což je dostatečné pro udržení fyzické zdatnosti. Spíše jsme očekávali hodnoty nižší než na rovině. Můžeme se domnívat, že je to způsobeno zejména brzdivým pohybem dolních končetin při pohybu $\mathrm{z}$ kopce, ale pro přesnější vysvětlení je třeba dalšího šetření. Při srovnání s výsledky naší starší studie pro chůzi prostou při rychlostech $4 \mathrm{a} 5 \mathrm{~km} / \mathrm{h}$ byly naše současné hodnoty SF při chůzi prosté nižší při chůzi na rovině a z kopce a významně vyšší př̀i chůzi do kopce (Korvas 2003).

Hodnoty tepového kyslíku i $\mathrm{VO}_{2} \max \left(\mathrm{ml} \mathrm{kg}^{-1} \cdot \mathrm{min}^{-1}\right)$ byly podle předpokladu zjištěny nejnižší u chůze z kopce a na rovině pro oba typy chůze. Podobně jako u SF jsme zjistili významně vyšší spotřebu kyslíku u chůze s holemi při vyšších rychlostech přesunu, na rovině u $6 \mathrm{~km} / \mathrm{h}$ a ve stoupání při $5 \mathrm{~km} / \mathrm{h}$ a 6 $\mathrm{km} / \mathrm{h}$. Pro $\mathrm{VO}_{2} \max \cdot \mathrm{kg}^{-1} \cdot \mathrm{min}^{-1}$ jsou námi zjištěné hodnoty nižší než nalezl např. Schwarz (2006) u stejně staré skupiny rekreačních turistů (12 subjektů) při chůzi, což má zřejmě souvislost s výkonnostní úrovní našeho probanda.

Při hodnocení poměru respirační výměny bylo $\mathrm{z}$ výsledků prokázáno jednoznačně aerobní zatížení u obou typů chůze na rovině i ve stoupání. Při chůzi na rovině s i bez holí hodnoty prokázaly při zvyšující se rychlosti sestupnou tendenci, což signalizuje zvyšování zapojení tukového metabolismu při vyšší rychlosti. Také při chůzi do kopce hodnoty prokázaly smíšené odbourávání tuků a cukrů v rozpětí 0,88-0,95. Nejvyrovnanější výsledek byl zjištěn u chůze do kopce s holemi $(0,88-0,90)$ pro všechny rychlosti. Při chůzi z kopce přesáhl poměr respirační výměny hodnotu $1,0(1,08$ až 1,24$)$. Při severské chůzi byly hodnoty nižší $(1,08-1,17)$ než při prosté chůzi $(1,24-1,20)$. V tomto případě to neznamenalo zapojení anaerobního metabolismu. Při chůzi z kopce se snížila ventilace, v jejímž důsledku poklesl i př́ijem kyslíku a setrvačnost výdeje $\mathrm{CO}_{2}$ zůstala na vyšší úrovni než spotřeba $\mathrm{O}_{2}$. Proto RER přesáhl hodnotu 1,0. Při srovnání s výsledky laboratorního spiroergometrického testu překonal proband respirační kvocient 1,0 při 132 tepech, což je hodnota, kterou při chůzi v terénu s holemi i bez nich nedosáhl. Výsledky RER $(0,88-0,96)$ vyšetřovaného jedince při chůzi na rovině a do kopce odpovídaly zatížení do $190 \mathrm{~W}$. K přechodu s většinovým zastoupením anaerobního metabolismu došlo při 220W. Přitom 200W je hranicí, při které $2 / 3$ populace končí při laboratorním vyšetření.

Zjištování energetické náročnosti je běžný způsob posouzení vhodnosti pohybové aktivity pro rozvoj nebo udržení fyzické kondice (Bunc, Teplý 1989, Bunc 1996, Suchý 2002 a další). I při srovnání výdeje energie byly zjištěny významné rozdíly mezi typy chůze až při vyšších rychlostech $(5$ a $6 \mathrm{~km} / \mathrm{h})$. Opět to naznačuje větší zapojení pletence ramenního a paže do tvorby hybných sil při rychlejší chůzi, která obvykle začíná na $5 \mathrm{~km} / \mathrm{h}$. Při chůzi z kopce výdej energie u obou typů chůze z kopce nebyl významně rozdílný při žádné rychlosti, což naznačuje hlavní zatížení pro dolní končetiny. Práce horních končetin proto neznamená výrazné zvýšení výdeje energie. V této studii jsme zjistili rozdílné hodnoty výdeje energie při prosté chůzi v terénu ve srovnání s naším starším výzkumem (Korvas 2003). Současné hodnoty byly vyšší při chůzi na rovině a z kopce, nižší při chůzi do kopce. Nejvíce se lišily hodnoty výdeje energie ve stoupání. V této starší studii byl zjištěn výdej energie při rychlostech 4 a $5 \mathrm{~km} / \mathrm{h}$ v rozsahu 0,2020,361 kJ, v současné 0,466-0,449 kJ. Při srovnání s hodnotami výdeje energie udávanými Buncem (1996) byly naše výsledky při chůzi prosté na rovině při rychlosti $4 \mathrm{~km} / \mathrm{h}$ srovnatelné $s$ jeho údaji pro 3-3,5km/ h (naše 0,189 respektive 0,190 kJ). Při vyšších rychlostech $(5$ a 6 km/h) jsou výsledky Bunce (1996) u průměrné populace vždy vyšší než bylo zjištěno u zdatného jedince (naše $0,223,0,277$, resp. 0,306, 0,422). 
Rozdíl může být zaprríčiněn efektivitou pohybu, technikou chůze u zkušeného a zdatného turisty. Výdej energie probanda do kopce při chůzi s holemi i bez holí při stejné rychlosti ve srovnání s chůzí na rovině byl vždy téměř dvojnásobně vyšší, to znamená dostatečně vysoký i pro rozvoj fyzické kondice. Při pravidelném pohybovém režimu ( $4 \mathrm{x}$ týdně) je možné ve střídavém terénu, ve kterém jsou pravidelně zastoupeny rovina, stoupání a klesání, dosáhnout potřebného dodatečného týdenního výdeje energie prostřednictvím chůze prosté v rozsahu 5000-6300 kJ nebo chůze severské 5100-7100 kJ v závislosti na rychlosti chůze. To jsou hodnoty, které pomáhají udržovat fyzickou zdatnost a můžeme je hodnotit jako dostatečné pro zisk zdravotních benefitů prostř̌ednictvím pohybových aktivit (Bunc, Teplý 1989, ASCM 1990, Pangrazi 1996, Blair 2001 a další).

\section{ZÁVĚRY}

Velikost rozdílů v intenzitě zatížení mezi chůzí prostou a severskou je pravděpodobně závislá na rychlosti přesunu a obtížnosti terénu. Čím jednodušší terén a nižší rychlost, tím menší rozdíly můžeme nalézt.

Při běžných rychlostech chůze do $5 \mathrm{~km} / \mathrm{h}$ na rovině a $\mathrm{z}$ kopce dosahuje intenzita zatížení u zdatnějšího chodce úrovně vhodné pro udržení základní fyzické zdatnosti. Pro rozvoj fyzické kondice je potřeba u zdatnějších jedinců vyšší rychlosti pohybu, na rovině od $6 \mathrm{~km} / \mathrm{h}$ a ve stoupáních od $5 \mathrm{~km} / \mathrm{h}$.

V př́padě pravidelné aktivity energetický výdej při chůzi prosté i severské je dostatečný pro získání zdravotních benefitů prostřednictvím pohybových aktivit.

\section{Literatura}

ASCM: The recommended quantity and quality of exercise for developing and maintaining fitness of healthy subjects. Med.Sci.Sports Exerc., 22,1990, s.265-274.

Bačáková,R., Kračmar,B., Škopek M. (2008a) Aktuální funkční změny v oblasti pánve při zapojení pletence ramenního do lokomoce. In Současný sportovní trénink. Sborník př́spěvků konf. Praha 23.1.2008. s. 223-227.

Bačáková, R., Tlašková, P., Kračmar, B. (2008b) Nordic Walking jako postrehabilitační pohybový režim. Studia Kinanthropologica. vol. 9, no. 1, pp. 53-58.

Blair,C.N., Dunn, A.L., Marcus, B.A., Carpenter, R.A., Jaret,P. (2001) Active living every day. Champaign, Human Kinetic, 245 p.

Bunc, V., Teplý, Z. (1989) Hodnocení energetické náročnosti základních tělesných aktivit. Čas. Lék. čes., 128, s. 1580-1583.

Bunc, V. (1996) Nové pohledy na minimální množství pohybových činností. TVSM, 62, 7, s.2-7

Ettinger, W.H., Wright, B.S., Blair, S.N. (2007) Fit po 50. Grada, Praha, 243 s. ISBN978-80-247-2203-0

Frömel, K., Novosad, J., Svozil, Z. (1999) Pohybová aktivita a sportovní zájmy mládeže. Olomouc: UP, 173 s., ISBN 80-7067-945-X

Korvas, P. (2003) Energy cost and intensity of load of hiker in various terrain conditions. In Acta Universitatis Matthiae Belii Physical Education and Sport. Vol.5, No.Bánská Bystrica, 5.s. 19-22.

Korvas, P. (2006) Srovnání výsledků měření energetického výdeje Kenzovým kalorimetrem a Sporttesterem Polar. Medicina Sportiva Bohemica et Slovaca, Praha, Česká společnost tělových. lékařství, 15, 1, od s. 23-28.

Kračmar, B., Novotný, P.O., Mrůzková M., Dufková, A., Suchý, J.(2007) Lidská lokomoce přes pletenec ramenní, Rehabilitácia vol. 44, č.1., Bratislava, s. 3-13

Pangrazi,R.P., Corbin,C.B., Welk,G.J. (1996) Physical activity for children and youth. J.Phys.Educ.Recr. Dance. 67,(4), s.38-43.

Schwarz,M., Urhausen,A., Schwarz,L., Meyer,T, Kindermann,W. (2006) Cardiocirculatory and metabolic responses at different walking intensities. Br.J.SportsMed. 40 (1), s.64-67.

Suchý, J.(2002) Možnosti řízení tréninkového procesu v triatlonu za využití energetické náročnosti, In Pohyb a výchova, Ústí nad Labem, PF, s.95-97, ISBN: 80-7044-450-9. 
Tlašková, P., Kračmar, B., Mrázková, M. Geneticky determinovaný pohybový program při zapojení svalů v oblasti ramenního pletence při nordic walking. Rehabilitácia, vol. 45, no. 2, pp. 67-73.

Vele,F. Kineziologie. (2006) Triton, Praha, s.374.

Zehr, E., Hundza, S., Vasudevan, E. (2009) The Quadrupedal Nature of Human Bipedal Locomotion. Exercise and Sport Sciences Reviews: Volume 37(2)April pp. 102-108

Zvonař, M. (2009) Involuce motorické výkonnosti dospělé populace. In Telesná výchova, šport, výskum na univerzitách. 1. vydání. Bratislava: Strojnická fakulta STU. s. 24-31. ISBN 978-80-227-3210-9 